\title{
TOWARDS THE SUSTAINABLE FOOD CONSUMPTION IN CENTRAL EUROPE: STOCHASTIC RELATIONSHIP BETWEEN WATER FOOTPRINT AND NUTRITION
}

\author{
O. TOMPA*, A. KISS and Z. LAKNER \\ Department of Food Economy, Faculty of Food Science, Szent István University, \\ H-1118, Budapest, Villányi út 29-43. Hungary
}

(Received: 15 July 2019; accepted: 2 October 2019)

\begin{abstract}
Sustainable nutrition (SN) considers the environmental impact of food production. This study aims to analyse the relationship between nutrient density and water footprint (WF) of the most consumed food items in Hungary and to create a classification of nutrients. Based on a comprehensive analysis of literature and different data sources, the authors analysed the stochastic relationship between WF and nutrient density of different food items by Spearman's rank correlation. The analysis proved significant $(\mathrm{P}<0.05)$ relationship between nutrient density and WF of the most relevant food items in Hungary. Based on the classification, there are nutrients that are overconsumed among the Hungarian population and positively correlate with WF (e.g., cholesterol) and there are nutrients that are underconsumed among the Hungarian population and negatively correlate with WF (e.g., dietary fibres). In general, it can be concluded that the re-structuration of food consumption patterns in Hungary is an important and urgent task, which serves both the public health and ecologic goals. These efforts should be based on a complex evaluation of the problem. This study was one initial step to analyse SN focused on Hungary and further studies are definitely needed.

Keywords: sustainability, nutrition, water footprint
\end{abstract}

Sustainable nutrition (SN) is a holistic approach that aims to create sustainable food security around the globe. SN includes a specific slice that considers the environmental burden of the food system. Despite intensive research on this topic, there is a gap of scientific publication from Central Eastern Europe according to systematic reviews on studies of SN (JONES et al., 2016; HALLSTRÖM et al., 2018). There is an urgent need to make a change in the recent food system to which SN can contribute. Developed, industrial countries hold the responsibility to act in order to reduce the ecological footprint of their food production (BÁNÁTI, 2009).

Nowadays, there is a growing attention on the ecological footprint of food items. The main environmental impact categories (EIC) are (1) Climate: greenhouse gas emission (GHGE), (2) Use of natural resources: land use, water use, and total resource use, (3) Emission of chemicals (S, N, and P), (4) Biodiversity (HALlström et al., 2018). Previous studies have calculated correlation between nutrient density (nutritional value/food or diet) and GHGE ( $\mathrm{CO}_{2}$ eq./food or diet) of food items or diets. Several studies have found significant correlation between nutrient density and GHGE of food items or diets (VIEUX et al., 2013; Drewnowski et al., 2015; HeNDrIE et al., 2016; vAN DoOrEn et al., 2017; SAARINEN et al., 2017). However, water footprint (WF) as an EIC to measure the ecological footprint of food items or diets is not often applied in similar studies (HALLSTRÖM et al., 2018).

\footnotetext{
* To whom correspondence should be addressed.

Phone: +36 30 2576720; e-mail: orsolya.tompa@olympian.org
} 
The aim and novelty of this study is that the analysis was based on the most consumed food items in Hungary and that water footprint was used as EIC. To take these calculations into an innovative aspect, nutrients were classified according to their intake level (based on the Hungarian Diet and Nutritional Status Survey (HDNSS), 2014) and water footprint. Results of this study will serve as a starting point of optimization of nutritional patterns of the population.

\section{Materials and methods}

\subsection{Estimation of the Hungarian food consumption}

For the estimation of food consumption, Food Balance Sheet of the Food and Agricultural Organization of the United Nations (FAO FBS) was used by several studies that analysed the relationship between nutrition and environmental impact (JONES et al., 2016). To analyse and specify the food consumption of Hungary, it was also necessary to use the database of Central Statistical Office of Hungary (CSO). FAO FBS provides data on the food supply of Hungary averaged in year/ $\mathrm{kg} /$ capita $(\mathrm{FAO}, 2013)$ and CSO provides data on the Hungarian food consumption averaged in year $/ \mathrm{kg} /$ capita $(\mathrm{CSO}, 2013)$. In the case of both databases, the dataset of 2013 was considered. These units were transformed to g/day/capita and only food items consumed in a reasonable amount ( $>4 \mathrm{~g} /$ day/capita) were included into the calculations. Finally, we listed 44 food items that are the most consumed in Hungary and they were used as a basis for the further calculations.

\subsection{Water footprint of the most consumed food items in Hungary}

Water footprint is a measure that indicates the amount of water usage of the production of a product over the complete supply chain, in other words: it is an indicator of water usage (Fogarassy \& NeUbeuer, 2016). Water footprint is specific for region, technology, and product. Water Footprint Network (WFN) published databases that are specific for countries and they contain data for a wide range of food items among crops (MEKONNEN \& HoEKSTRA, 2010a) and among animal-based foods (MeKonnen \& Hoekstra, 2010b). According to LUKAS and co-workers (2016), the databases of WFN are the best free and available option to calculate with the water footprint of foods, so the specific data on the water footprint of single food items produced in Hungary were acquired from WFN. In the case of palm oil, soy oil, cocoa beans, orange, and banana the global average of water footprint was considered, since they are not produced in Hungary. There are three types of water footprint: green, blue, and grey. In this study, only green water footprint (GWF) was included into the calculation. Grey water footprint was excluded due to missing data. Calculation and statistical analysis were also applied with the inclusion of blue water footprint, but it was excluded afterwards, because it did not lead to any new conclusion.

\subsection{Correlation between nutrient density and water footprint of the different food items}

Two types of variables were included into the calculations: nutrient density and GWF of the 44 most consumed food items. Nutrient composition data were acquired from USDA database (Nutrient Data Laboratory (U.S.) \& CONSUmer ANd Food ECONOMics Institute (U.S.), 1999). To test the correlation between the variables, Spearman's rank correlation was selected over Pearson correlation, since not all of the assumptions of Pearson correlation were 
satisfied, such as the normality of variables, which were not normally distributed. It was proven by one sample Kolmogorov-Smirnov test. Correlation was calculated with energy and nutrient density (nutritional value/100 g) and GWF $\left(1 \mathrm{~kg}^{-1}\right)$ as variables. VAN Dooren and co-workers (2017) applied the same calculation with GHGE as EIC.

The significance level was adjusted to alpha $=0.05$ in each calculation. Calculations were performed with IBM SPSS Statistics ${ }^{\circledR}$ v. 25 .

\subsection{Classification of nutrients}

Analysed nutrients were classified based on their average intake among the Hungarian population and their correlation with GWF. The average intake of nutrients of the Hungarian population was based on the published data of the HDNSS that was made in 2014. This survey was representative for the Hungarian population and determined the nutritional status and the average intake of nutrients. These average intake levels were compared to the Hungarian nutrient reference values (NRVs) (SARKADI NAgY et al., 2017; SchreIBERnÉ Molnár et al., 2017). The methodology is summarized in Figure 1.

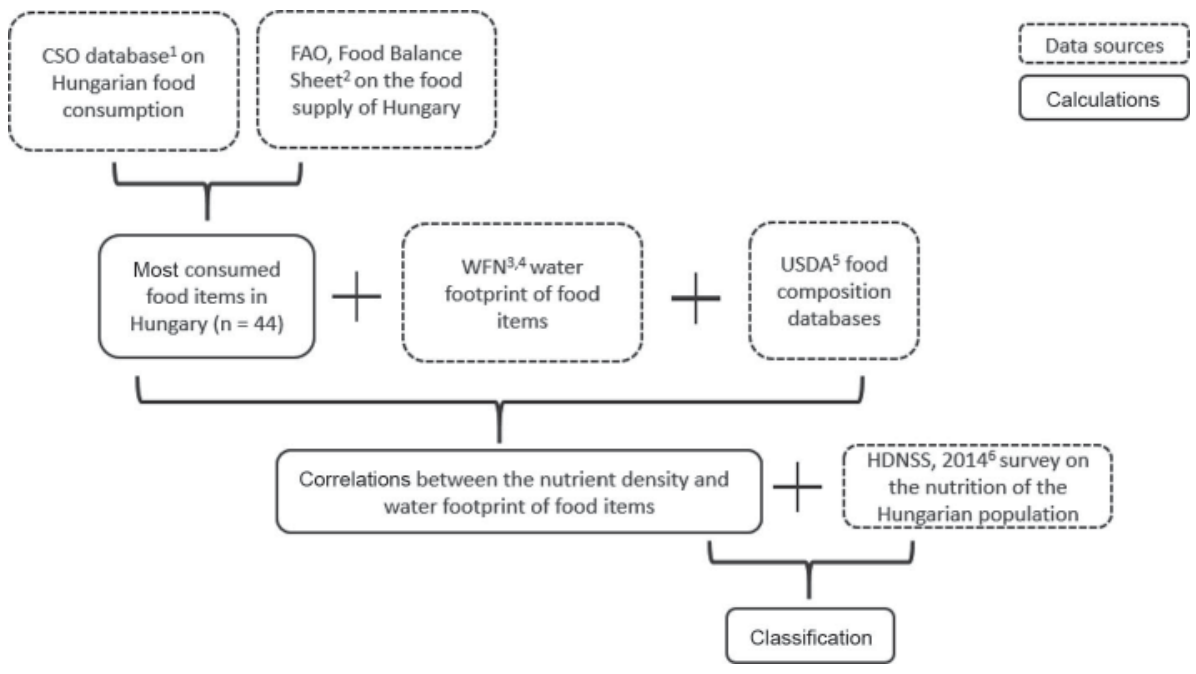

Fig. 1. Flow chart of databases and calculations (1: Central Statistical Office of Hungary, 2: Food and Agriculture Organization of the United Nation, 3,4: Water Footprint Network, 5: U.S. Department of Agriculture, 6: Hungarian Diet and Nutritional Status Survey, 2014)

\section{Results and discussion}

\subsection{Correlation between nutrient density and water footprint}

For both calculations, significant results were assumed, since GHGE as an indicator of environmental impact factors can predict correlation for other EICs such as GWF (van DoOREN et al., 2017). Several studies have proved relationship between nutrient density and GHGE of food items, and they were used as comparisons to the results of this study.

Spearman's rank correlation showed significant correlations between numerous nutrient density values with GWF (Table 1). Previous studies have found significant correlation either 
between the energy density of diets and GHGE (VIEUX et al., 2013; HeNDRIE et al., 2016) or energy density of food items and GHGE (DREWNOWSKi et al., 2015; VAN Dooren et al., 2017). SAARINEN and co-workers (2017) have also calculated significant correlation with folate and protein with GHGE. In another similar study, significant correlation had also been proved between total protein and saturated fatty acids and GHGE (VAN DoOREN et al., 2017). There was no significant correlation between any analysed minerals and GWF, despite the findings of VAN DOOREN and co-workers (2017) and SAARINEN and co-workers (2017). The positive results of VAN DOOREN and co-workers (2017) can be explained by the fact that they have analysed 403 food items, while in this study only 44 food items were analysed. However, SAARINEN and co-workers (2017) have analysed only 29 food items and found significant positive correlation with mineral density and GHGE.

Table 1. Spearman's rank correlation between nutrient density (nutritional value/100 g) and green water footprint $\left(1 \mathrm{~kg}^{-1}\right)$ of the most consumed food items in Hungary

\begin{tabular}{lcc}
\hline & Correlation coefficient $(\mathrm{r})$ & Significance $(\mathrm{p})$ \\
\hline Energy $(\mathrm{kcal})$ & $0.715^{* *}$ & 0.000 \\
Total carbohydrates $(\mathrm{g})$ & $-0.311^{*}$ & 0.040 \\
Dietary fibre $(\mathrm{g})$ & $-0.367^{*}$ & 0.014 \\
Sugar $(\mathrm{g})$ & $-0.322^{*}$ & 0.033 \\
Total protein $(\mathrm{g})$ & $0.331^{*}$ & 0.028 \\
Cholesterol $(\mathrm{mg})$ & $0.570^{* *}$ & 0.000 \\
Total lipid $(\mathrm{g})$ & $0.756^{* *}$ & 0.000 \\
Saturated fatty acids $(\mathrm{g})$ & $0.701^{* *}$ & 0.000 \\
Thiamin $(\mathrm{mg})$ & -0.033 & 0.830 \\
Riboflavin $(\mathrm{mg})$ & $0.322^{*}$ & 0.033 \\
Niacin $(\mathrm{NE})$ & 0.0412 & 0.787 \\
Vitamin B6 $(\mathrm{mg})$ & -0.056 & 0.719 \\
Folate $(\mu \mathrm{g})$ & $-0.386^{* *}$ & 0.010 \\
Vitamin B12 $(\mu \mathrm{g})$ & $0.574^{* *}$ & 0.000 \\
Vitamin C $(\mathrm{mg})$ & $-0.643^{* *}$ & 0.000 \\
Vitamin A $(\mu \mathrm{g})$ & -0.238 & 0.119 \\
Vitamin E $(\mathrm{mg})$ & 0.274 & 0.071 \\
Vitamin K $(\mu \mathrm{g})$ & -0.164 & 0.286 \\
\hline
\end{tabular}

$(\mathrm{n}=44)$. Correlation is significant at the 0.01 level $^{* *}$ and 0.05 level *.

\subsection{Classification of nutrients}

According to the recommended intake level and measured intake level of nutrients - based on HDNSS - and the correlation with GWF of nutrients, they can be classified as:

i. The average intake of the Hungarian population is lower than the NRV.

ii. The average intake of the Hungarian population is higher than the NRV.

a. There is a significant negative correlation between nutrient density and GWF.

b. There is a significant positive correlation between nutrient density and GWF.

Based on these two aspects, nutrients were classified into four groups (Figure 3). Group (i.a.) includes nutrients that are underconsumed and have a low association with GWP, they are typically high in plant-based foods. Group (ii.b.) includes nutrients that are overconsumed and have a high association with GWP, they are typically high in animal-based foods. Group 
(i.b.) contains riboflavin, there was a significant positive correlation with GWF, and its intake does not reach the recommendation. However, the difference between the average intake (men: 1.46 and women: $1.24 \mathrm{mg}$ day $^{-1}$ ) and NRVs (men: 1.6 and women: $1.3 \mathrm{mg} \mathrm{day}^{-1}$ ) is not considerably big (SCHREIBERNÉ MolnÁR et al., 2017). Riboflavin content is high in animalbased foods, but it is also found in pulses and grains in a considerable amount. Group (ii.a.) includes vitamin $\mathrm{C}$ that is somehow a controversy result, because nutrients that are typically high in vegetables and fruits and negatively correlate with GWF belong to group (i.a.). However, the average intake of vitamin $\mathrm{C}$ of the Hungarian population exceeds the NRV. Total protein cannot be classified into any given group, since there was a significant, positive correlation with its density in food items and GWF of them but the average intake of it among the Hungarian population meets with the NRV. In case of sugar, despite that there was significant negative correlation between its density and GWF in food items, it cannot be classified, because the NRV considers added sugar, while the calculation was based on both added and natural sugar content.

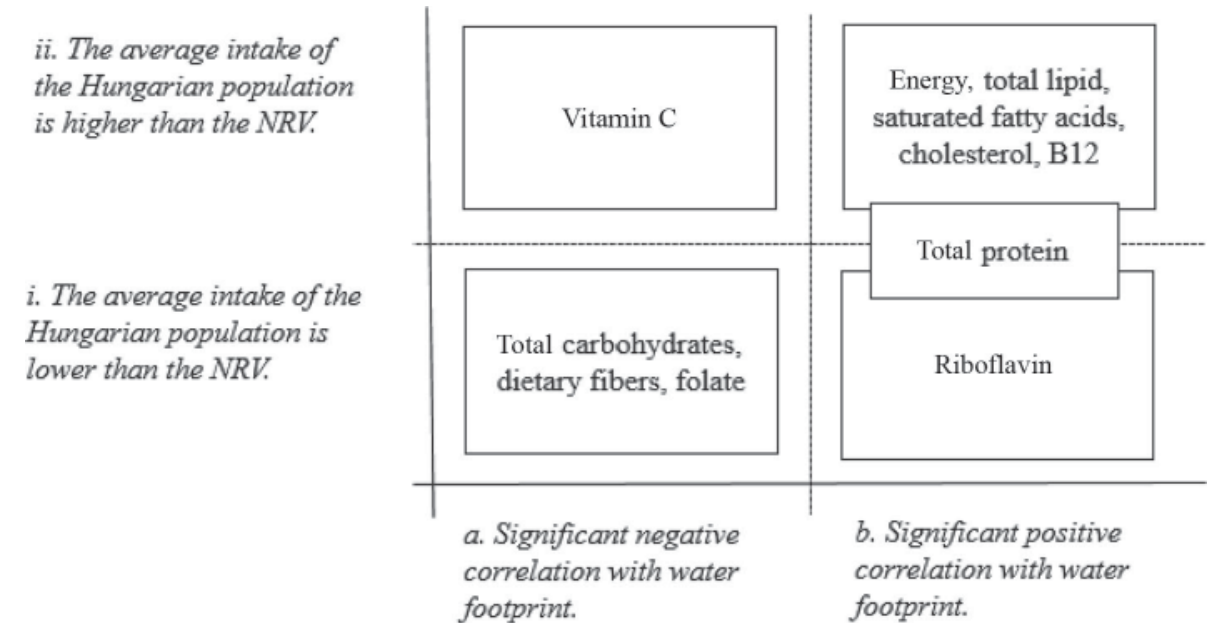

Fig 2. Classification of nutrients based on their average intake among the Hungarian population compared to nutrient reference values (NRVs) and significant correlation with green water footprint (GWF)

\section{Conclusions}

As it was assumed, numerous nutrient density values of food items have significant correlation with GWF. The classification applied in this paper discusses these results from a new aspect based on the intake level of nutrients among the Hungarian population. According to this approach, overconsumed (i.e. "unhealthy ") nutrients that are associated with health risks have a high association with GWF. On the other hand, underconsumed (i.e. "healthy") nutrients - that are considered to be preventive factors in the aspect of health - have a low association with GWF. This study was based on the results of HDNSS 2014 (SARKADI NAGY et al., 2017; SCHREIBERnÉ MolnÁR et al., 2017) that represent the nutritional habits of the Hungarian population from a cross-sectional view. However, "there is nothing new under the 
sun", the inadequate intake of nutrients had also been present in the last quarter of the century (SzEITZ-SzABó et al., 2012). It was one of the initial steps to focus the analysis of the SN on Hungary and further studies are definitely needed.

The study was supported by the Doctoral School of Food Sciences at Szent István University. The Project is supported by the European Union and co-financed by the European Social Fund (grant agreement no. EFOP-3.6.3VEKOP-16-2017-00005).

\section{References}

BÁNÁTI, D. (2009): Editorial — Food production and ecological footprints. Acta Alimentaria, 38, 151-152. https:// doi.org/10.1556/aalim.38.2009.2.2

CSO (CEnTRAL STATISTICAL OfFice (2013): 2.2.3.6. Amount of food consumption per capita per year classified by income and type of region into deciles (2010-). Available at: https://www.ksh.hu/docs/hun/xstadat/xstadat_ eves/i_zhc023a.html. (last accessed: 26 June 2019)

Drewnowski, A., Rehm, C.D., Martin, A., Verger, E.O., Voinnesson, M. \& Imbert, P. (2015): Online supplemental material: Energy and nutrient density of foods in relation to their carbon footprint. Am. J. Clin. Nutr., 101(1), 184-191.

FAO (2013): Food Balance Sheet. Available at: http://www.fao.org/faostat/en/\#data/FBS (last accessed: 24 June 2019)

Fogarassy, C. \& Neubauer, E. (2016): Evaluation of the regional water usage in Hungary with water allowance coefficient (WAC). Appl. Ecol. Env. Res., 14(1), 161-173.

Hallström, E., Davis, J., Woodhouse, A. \& Sonesson, U. (2018): Using dietary quality scores to assess sustainability of food products and human diets: A systematic review. Ecol. Indic., 93, 219-230.

Hendrie, G.A., Baird, D., Ridoutt, B., Hadjikakou, M. \& Noakes, M. (2016): Overconsumption of energy and excessive discretionary food intake inflates dietary greenhouse gas emissions in Australia. Nutrients, 8(11). https://doi.org/10.3390/nu8110690

Jones, A.D., Hoey, L., Blesh, J., Miller, L., Green, A. \& Shapiro, L.F. (2016): A systematic review of the measurement of sustainable diets. Adv. Nutr., 7(4), 641-664.

Lukas, M., Rohn, H., Lettenmeier, M., Liedtke, C. \& Wiesen, K. (2016): The nutritional footprint - integrated methodology using environmental and health indicators to indicate potential for absolute reduction of natural resource use in the field of food and nutrition. J. Clean. Prod., 132, 161-170.

Mekonnen, M.M. \& Hoekstra, A.Y. (2010a): The green, blue and grey water footprint of crops and derived crop products. Value of water research report Series No. 47, UNESCO-IHE, Delft, the Netherlands. Available at: http://www.waterfootprint.org/Reports/Report47-WaterFootprintCrops-Vol1.pdf (last accessed: 26 June 2019)

Mekonnen, M.M. \& Hoekstra, A.Y. (2010b): The green, blue and grey water footprint of farm animals and animal products. Value of water research report Series No. 48, UNESCO-IHE, Delft, the Netherlands. Available at: https://waterfootprint.org/media/downloads/Report-48-WaterFootprint-AnimalProducts-Vol1_1.pdf (last accessed: 26 June 2019)

Nutrient Data Laboratory (U.S.) \& Consumer and Food Economics Institute (U.S.) (1999): USDA nutrient database for standard reference. Riverdale, Md: USDA, Nutrient Data Laboratory, Agricultural Research Service. Available at: https://ndb.nal.usda.gov/ndb/search/list (last accessed: 26 June 2019)

SaArinen, M., Fogelholm, M., Tahvonen, R. \& Kurppa, S. (2017): Taking nutrition into account within the life cycle assessment of food products. J. Clean. Prod., 149, 828-844.

Sarkadi Nagy, E., BaKacs, M., Illés, É., Nagy, B., VArga, A., .. \& Martos, É. (2017): Országos Táplálkozás és Tápláltsági Állapot Vizsgálat - OTÁP2014. II. A magyar lakosság energia- és makrotápanyag-bevitele. (Hungarian Diet and Nutritional Status Survey - HDNSS 2014 II. Energy and macronutrient intake of the Hungarian population). Orvosi Hetilap, 158(15), 587-597. 
Schreiberné Molnár, E., Nagy-Lőrincz, Z., Nagy, B., BaKacs, M., Kis, O., .. \& Martos, É. (2017): Országos Táplálkozás- és Tápláltsági Állapot Vizsgálat - OTÁP2014. V. A magyar lakosság vitaminbevitele (Hungarian Diet and Nutritional Status Survey - HDNSS 2014 II. Vitamin intake of the Hungarian population). Orvosi Hetilap, 158(33), 1302-1313. https://doi.org/10.1556/650.2017.30832

Szeitz-Szabó, M., Biró, L. \& Biró, G. (2012): Nutritional and vital statistical features of the Hungarian population: A review about the past 25 years. Acta Alimentaria, 41, 277-291.

van Dooren, C., Douma, A., Aiking, H. \& Vellinga, P. (2017): Proposing a novel index reflecting both climate impact and nutritional impact of food products. Ecol. Econ., 131, 389-398.

Vieux, F., Soler, L., Touazi, D. \& Darmon, N. (2013): High nutritional quality is not associated with low greenhouse gas emissions in self-selected diets. Am. J. Clin. Nutr., 97, 569-583.

Open Access statement. This is an open-access article distributed under the terms of the Creative Commons Attribution 4.0 International License (https://creativecommons.org/licenses/by/4.0/), which permits unrestricted use, distribution, and reproduction in any medium, provided the original author and source are credited, a link to the CC License is provided, and changes - if any - are indicated. (SID_1) 